\title{
Definitions of Normal Liver Fat and the Association of Insulin Sensitivity with Acquired and Genetic NAFLD-A Systematic Review
}

\author{
Elina M. Petäjä ${ }^{1,2, *}$ and Hannele Yki-Järvinen ${ }^{1,2}$ \\ 1 Minerva Foundation Institute for Medical Research, 00290 Helsinki, Finland; \\ hannele.yki-jarvinen@helsinki.fi \\ 2 Department of Medicine, University of Helsinki and Helsinki University Central Hospital, \\ 00290 Helsinki, Finland \\ * Correspondence: elina.petaja@helsinki.fi; Tel./Fax: +358-9-471-71967
}

Academic Editors: Amedeo Lonardo and Giovanni Targher

Received: 3 March 2016; Accepted: 20 April 2016; Published: 27 April 2016

\begin{abstract}
Non-alcoholic fatty liver disease (NAFLD) covers a spectrum of disease ranging from simple steatosis (NAFL) to non-alcoholic steatohepatitis (NASH) and fibrosis. "Obese/Metabolic NAFLD" is closely associated with obesity and insulin resistance and therefore predisposes to type 2 diabetes and cardiovascular disease. NAFLD can also be caused by common genetic variants, the patatin-like phospholipase domain-containing 3 (PNPLA3) or the transmembrane 6 superfamily member 2 (TM6SF2). Since NAFL, irrespective of its cause, can progress to NASH and liver fibrosis, its definition is of interest. We reviewed the literature to identify data on definition of normal liver fat using liver histology and different imaging tools, and analyzed whether NAFLD caused by the gene variants is associated with insulin resistance. Histologically, normal liver fat content in liver biopsies is most commonly defined as macroscopic steatosis in less than $5 \%$ of hepatocytes. In the population-based Dallas Heart Study, the upper 95th percentile of liver fat measured by proton magnetic spectroscopy $\left({ }^{1} \mathrm{H}-\mathrm{MRS}\right)$ in healthy subjects was $5.6 \%$, which corresponds to approximately $15 \%$ histological liver fat. When measured by magnetic resonance imaging (MRI)-based techniques such as the proton density fat fraction (PDFF), $5 \%$ macroscopic steatosis corresponds to a PDFF of $6 \%$ to $6.4 \%$. In contrast to "Obese/metabolic NAFLD", NAFLD caused by genetic variants is not associated with insulin resistance. This implies that NAFLD is heterogeneous and that "Obese/Metabolic NAFLD" but not NAFLD due to the PNPLA3 or TM6SF2 genetic variants predisposes to type 2 diabetes and cardiovascular disease.
\end{abstract}

Keywords: insulin resistance; liver fat; obesity; PNPLA3; TM6SF2

\section{Introduction}

Non-alcoholic fatty liver disease (NAFLD) is defined as steatosis not caused by excess alcohol intake (>30 g/day in men and $>20 \mathrm{~g} /$ day in women), hepatitis B or C, autoimmune hepatitis, iron overload, drugs or toxins [1]. It covers a spectrum from simple steatosis (NAFL) to non-alcoholic steatohepatitis (NASH) and cirrhosis [1,2]. NASH is characterized, in addition to steatosis, by ballooning necrosis, mild inflammation and possibly fibrosis, and can only be diagnosed using a liver biopsy [3].

Several longitudinal studies have shown that NAFLD increases the risk of and mortality from type 2 diabetes and cardiovascular disease [4]. Fibrosis stage is considered to be the most important histological feature predicting advanced liver disease [5,6]. It has been recently shown, however, that NAFL defined as macroscopic steatosis in more than $5 \%$ of hepatocytes progresses to NASH and 
fibrosis [7-9], as hypothesized by earlier indirect evidence [10]. Thus, NAFL predicts both metabolic and liver complications of NAFLD. It is therefore of interest to define normal liver fat content in humans.

Although NAFLD commonly coexists with obesity, insulin resistance and type 2 diabetes [11], common genetic causes also exist. A variant in patatin-like phospholipase domain-containing 3 (PNPLA3) (rs738409 [G], encoding I148M) confers susceptibility to NAFL, NASH and fibrosis ("PNPLA3 NAFLD") [12]. Genetic variation in transmembrane 6 superfamily member 2 (TM6SF2) (rs58542926 [T], encoding E167K) is also increases liver fat and the risk of NASH ("TM6SF2 NAFLD") [13]. These two conditions do not appear to be characterized by insulin resistance, although both genetic and metabolic causes of NAFLD may exist in the same person [14]. If so, then these types of NAFLD would not predispose to type 2 diabetes and cardiovascular disease.

The ensuing review will focus on defining normal liver fat content and discussing how liver fat content is related to insulin sensitivity in "Obese/Metabolic NAFLD" and the common genetic forms of NAFLD.

\section{Definitions of Normal Liver Fat}

\subsection{Biochemical and Histologic Definitions}

The biochemical standard for normal triglyceride content in the human liver is $5.5 \%$ of triglyceride of wet liver tissue weight $[15,16]$. Histologically, the liver is considered steatotic when $\geqslant 5 \%$ of hepatocytes in a tissue section stained with hematoxylin and eosin contain macrovesicular steatosis [17-20]. Steatosis is graded by the pathologist from 0 to 3 based on its severity: grade 0 (normal) $=<5 \%$, grade $1($ mild $)=5 \%-33 \%$, grade 2 (moderate) $=34 \%-66 \%$, and grade $3($ severe $)=\geqslant 67 \%$ of hepatocytes characterized by macroscopic steatosis [17]. As discussed below, these percentages seem quite different from those obtained by proton magnetic resonance spectroscopy $\left({ }^{1} \mathrm{H}-\mathrm{MRS}\right)$ (Table 1).

Table 1. Definitions of normal liver fat using different approaches.

\begin{tabular}{|c|c|c|c|c|}
\hline Study & Year & $N$ & Subjects & Normal Value \\
\hline \multicolumn{5}{|c|}{ Biochemical } \\
\hline Laurell S [21] & 1971 & 3 & Healthy subjects & $2.0 \mathrm{~g} / 100 \mathrm{~g}$ of dry tissue weight \\
\hline Donhoffer H [15] & 1974 & 107 & Unselected cadavers & $5.5 \mathrm{~g} / 100 \mathrm{~g}$ of wet tissue weight \\
\hline \multicolumn{5}{|c|}{ Histology } \\
\hline Kleiner DE [17] & 2005 & $576+162$ & Adults and children & Macroscopic fat in $<5 \%$ of hepatocytes \\
\hline Brunt EM [3] & 2011 & 976 & Adults & Macroscopic fat in $<5 \%$ of hepatocytes \\
\hline Bedossa P [19] & 2012 & 679 & $\begin{array}{l}\text { Morbidly obese } \\
\text { adults }\end{array}$ & Macroscopic fat in $<5 \%$ of hepatocytes \\
\hline \multicolumn{5}{|c|}{$C T$} \\
\hline Piekarski J [22] & 1980 & 100 & Healthy subjects & $50-57 \mathrm{HU}$ or $8-10 \mathrm{HU}$ higher than spleen \\
\hline \multicolumn{5}{|c|}{${ }^{1} H-M R S$} \\
\hline Szczepaniak LS [23] & 2005 & 345 & $\begin{array}{l}\text { Population-based, } \\
\text { healthy subjects }\end{array}$ & $<5.56 \%$ \\
\hline Petersen KF [24] & 2006 & 170 & Healthy subjects & $<3.0 \%$ \\
\hline \multicolumn{5}{|c|}{ MRI-PDFF } \\
\hline Fishbein MH [25] & 1998 & 28 & Healthy subjects & $<9.0 \%$ \\
\hline \multicolumn{5}{|c|}{ US } \\
\hline Joseph AE [26] & 1978 & 60 & $\begin{array}{l}\text { Adults referred to } \\
\text { gastroenterologist }\end{array}$ & Absense of echogenicity or brightness of the liver \\
\hline Saveymuttu SH [27] & 1985 & 490 & $\begin{array}{l}\text { Adults referred to } \\
\text { gastroenterologist }\end{array}$ & Absense of echogenicity or brightness of the liver \\
\hline
\end{tabular}




\subsection{Proton Magnetic Resonance Spectroscopy $\left({ }^{1} H-M R S\right)$}

Steatosis can most accurately be measured using ${ }^{1} \mathrm{H}-\mathrm{MRS}$ [28]. This technique enables sampling of a large volume fraction of the liver compared to a biopsy $[29,30]$ and provides an accurate and reproducible measurement of liver fat content [30]. However, ${ }^{1} \mathrm{H}-\mathrm{MRS}$ is expensive, as it requires use of magnetic resonance imaging (MRI) scanner and special expertise to perform proton magnetic resonance spectroscopy $\left({ }^{1} \mathrm{H}-\mathrm{MRS}\right)$ at the time of MRI scanning. ${ }^{1} \mathrm{H}-\mathrm{MRS}$ has been used in one population-based study, the Dallas Heart Study (DHS), to define normal liver fat content [23]. In this study, ${ }^{1} \mathrm{H}$-MRS was performed on 2349 subjects, of which 345 were considered healthy based on the following criteria: no history of liver disease or risk factors for hepatic steatosis (alcohol consumption $\leqslant 30 \mathrm{~g} /$ day in men, $\leqslant 20 \mathrm{~g} /$ day in women, body mass index (BMI) $<25 \mathrm{~kg} / \mathrm{m}^{2}$, normal fasting serum glucose, non-diabetic and normal serum alanine aminotransferase (ALT) $(\leqslant 30 \mathrm{IU} / \mathrm{L}$ in men, $\leqslant 19 \mathrm{IU} / \mathrm{L}$ in women)). The upper limit of normal liver fat content was defined based on the upper 95th percentile in the healthy subjects and was 5.56\% [23].

The ${ }^{1} \mathrm{H}$-MRS studies determine the hepatic triglyceride content rather than the percentage of hepatocytes with macroscopic lipid droplets. The relationship between ${ }^{1} \mathrm{H}-\mathrm{MRS}$ and histological liver fat content has been analyzed in two small studies, which included 13 [31], 12 [32] and 50 [33] subjects. In the first two studies, the ${ }^{1} \mathrm{H}$-MRS-determined normal liver fat in the DHS, i.e., the $5.56 \%$ value corresponded to $15.7 \%$ [31] and 13.9\% [32] of hepatocytes with macroscopic steatosis. On the third study, histological grade 1 ( $5 \%-33 \%$ macroscopic liver fat) corresponded to $11 \%(7 \%-14 \%)$, grade $2(33 \%-66 \%)$ to $18 \%(14 \%-23 \%)$ and grade $3(>66 \%)$ to $25 \%(10 \%-28 \%){ }^{1} \mathrm{H}-\mathrm{MRS}$ liver fat [33]. ${ }^{1}$ H-MRS-measured liver fat corresponds well to triglyceride content measured in a liver biopsy $(r=0.90$, $p<0.001)$ [34]. These data show that the technique used to define normal liver fat influences the normal value.

\subsection{Magnetic Resonance Imaging (MRI)}

Hepatic steatosis can be diagnosed with MRI using an out-of-phase and in-phase imaging technique developed by Dixon WT et al. [35]. This method involves acquisition of MR images at echo times in which fat proton and water proton signals are either out-of-phase (water and fat signals cancel) or in-phase (water and fat signals add up) [35-37]. Once the out-of-phase and in-phase images are acquired by using constant calibration and other scanner settings, a quantitative fat signal fraction can be calculated from the hepatic signal [38]. Modified versions of the early Dixon method have been introduced. These include the hepatic fat fraction by Fishbein MH et al. which uses fast gradient echo techniques $[25,39]$ and correlates well with histological liver fat content $(r=0.77, p<0.001)$. The newer MRI-determined proton density fat fraction (PDFF) technique provides a quantitative, standardized and objective MRI measurement of hepatic fat based upon inherent tissue properties $[40,41]$. The MRI-PDFF method is reproducible and correlates closely with ${ }^{1} \mathrm{H}-\mathrm{MRS}$ $(r=0.99)[33,42]$ and liver histology $(8.9 \%-9.4 \%$ at grade $1,15.8 \%-16.3 \%$ at grade 2 , and $22.1 \%-25.0 \%$ at grade $3, p<0.0001)[33,43,44]$. With this technique, the $5 \%$ macroscopic liver fat determined by histology corresponds to a PDFF value of $6 \%$ to $6.4 \%[45,46]$.

\subsection{Ultrasound (US)}

Ultrasound (US) is an inexpensive and widely available tool to visualize the liver and its fat content. Hepatic steatosis appears as a diffuse increase in parenchymal brightness and echogenicity on US images, and is often compared to hypoechogenity of the kidney cortex. Most studies score steatosis semiquantitatively as "mild", "moderate" and "severe" based upon the visual assessment of hepatic echogenicity [27,47-49]. Lack of standardization precludes accurate comparison of data acquired by different machines and investigators. US lacks sensitivity in obese subjects [50] and in subjects with low liver fat content [51]. The sensitivity of diagnosing fatty liver increases from $55 \%$ to $80 \%$ when liver fat increases from $10 \%-20 \%$ to over $30 \%$ [51]. A recent study [52] suggested that 
the optimum sensitivity for US was achieved at a ${ }^{1} \mathrm{H}$-MRS-measured liver fat content greater than $12.5 \%$. A meta-analysis of 44 studies comprising 4720 subjects concluded that US has a sensitivity of $85 \%$ and a specificity of $94 \%$ for detecting $20 \%-30 \%$ macroscopic steatosis [53]. The sensitivity and specificity were $65 \%$ and $81 \%$ for detecting $0 \%-5 \%$ steatosis and $93 \%$ and $88 \%$, respectively, for detecting $>10 \%$ steatosis.

Xia MF et al. created an equation for accurate quantification of liver fat content using US in Chinese subjects [54]. A tissue-mimicking phantom was used as a standard and the US hepatic/renal ratio was measured to calculate liver fat content in 127 subjects, in whom liver fat was also measured using ${ }^{1} \mathrm{H}$-MRS. The adjusted $\mathrm{R}^{2}$ for the model was $80 \%$. The optimal cut-off for the US-measured liver fat content to diagnose hepatic steatosis was $9.15 \%$, which yielded a sensitivity and specificity of $95 \%$ and $100 \%$, respectively. The utility of this technique in other ethnic groups which are more obese than the Chinese in the face of a similar amount of liver fat $[55,56]$ remains to be tested.

\subsection{Computed Tomography (CT)}

Hepatic steatosis can also be assessed by using computed tomography (CT) by comparing attenuation of the liver parenchyma to that of the spleen [57]. Tissue fat deposition lowers attenuation, hence fatty areas are less dense and appear darker than the non-fatty tissues [22]. The attenuation value in the healthy liver is 50 to 57 Houndsfield Units (HU) and 8 to $10 \mathrm{HU}$ higher than that of spleen [22]. It decreases by $1.6 \mathrm{HU}$ for every $1 \mathrm{mg}$ of triglycerides per gram of liver tissue [58]. In subjects with steatosis, the mean attenuation value of the liver is lower than that of the spleen, and the liver appears darker than the spleen. Attenuation values less than $40 \mathrm{HU}$ in the liver or $10 \mathrm{HU}$ less in the liver than in the spleen are indicative of marked hepatic steatosis $(>30 \%)$. Smaller fractions of fatty infiltration cannot be accurately and reliably assessed $[59,60]$.

\section{Non-Alcoholic Fatty Liver Disease (NAFLD) and Insulin Sensitivity}

\subsection{Insulin Resistance in "Obese/Metabolic NAFLD"}

In subjects with NAFLD and the metabolic syndrome (MetS), i.e., in "Obese/Metabolic NAFLD", liver fat is closely correlated with direct measures of insulin resistance such as the inability of insulin to suppress hepatic glucose production [61], and indirect measures such as fasting serum insulin and the product of fasting insulin and glucose (Homeostasis model assessment for insulin resistance [HOMA-IR]) [62]. Indeed, liver fat correlates better with fasting insulin than with liver enzymes such as serum ALT and aspartate aminotransferase (AST) [63,64]. This close association between fasting insulin and liver fat is physiologically feasible as the main action of insulin after an overnight fast is to restrain hepatic glucose production. The inability of insulin to suppress hepatic glucose production increases fasting glucose, which stimulates insulin secretion leading to hyperglycemia and hyperinsulinemia.

Lipolysis is the main source of fatty acids used for synthesis of intrahepatocellular triglycerides $[65,66]$. Liver fat is closely correlated with the ability of insulin to suppress lipolysis $[67,68]$. The ability of insulin to suppress very low density lipoprotein (VLDL) production is also impaired in NAFLD, which contributes to hypertriglyceridemia and a low high density lipoprotein (HDL) cholesterol concentration. Damaged hepatocytes release increased amounts of C-reactive protein (CRP) and coagulation factors, which could contribute to increased risk of cardiovascular disease and atherothrombotic vascular disease (Figure 1).

Any obese person with NAFLD and features of the MetS can be considered to have "Obese/Metabolic NAFLD" irrespective of genetic risk factors. The most recent proposal defines the MetS in 10 different ways [69]. The presence of any three out of five features (hypertriglyceridemia, low HDL cholesterol, hyperglycemia, hypertension, increased waist circumference) is required for diagnosis of the MetS [69]. For clinical practice, this definition still remains the best tool to diagnose insulin resistance, although the extent to which the 10 different definitions increase the risk of endpoints 
such as type 2 diabetes and cardiovascular disease is unclear. Measurement of fasting insulin and glucose concentrations and their calculation of their product HOMA-IR might seem more attractive direct tools to measure insulin sensitivity in subjects with NAFLD. The problem with this approach is that insulin assays are not internationally standardized and give highly variable results [70].

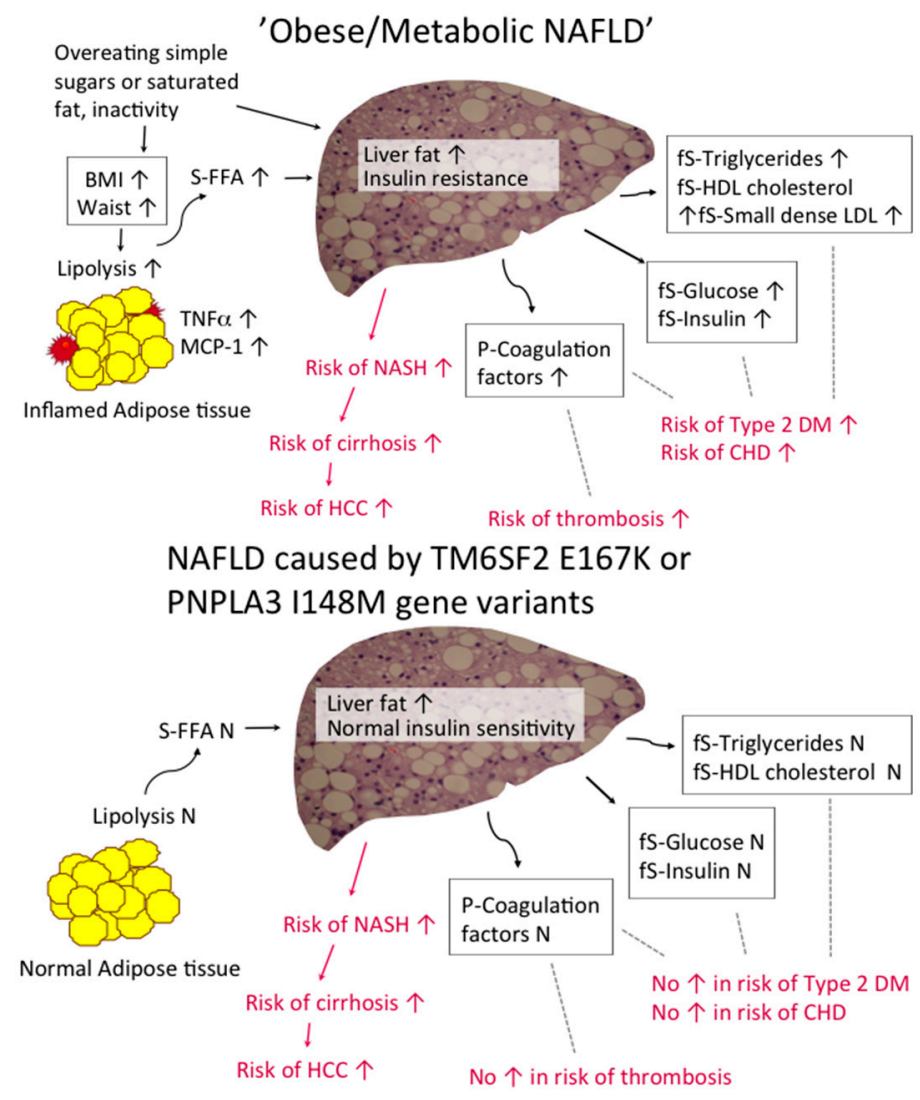

Figure 1. Schematic representation of causes and consequences of "Obese/Metabolic NAFLD" (top) and "TM6SF2 NAFLD" and "PNPLA3 NAFLD" (bottom). Abbreviations: BMI, body mass index; CHD, coronary heart disease; DM, diabetes mellitus; FFA, free fatty acids; fS, fasting serum; HCC, hepatocellular carcinoma; HDL, high density lipoprotein; MCP-1, monocyte chemoattractant protein-1; NAFLD, non-alcoholic fatty liver disease; NASH, non-alcoholic steatohepatits; LDL, low density lipoprotein; P, plasma; PNPLA3, patatin-like phospholipase domain-containing 3; S, serum; TM6SF2, transmembrane 6 superfamily member 2 ; TNF- $\alpha$, tumor necrosis factor- $\alpha$.

\section{2. "Patatin-Like Phospholipase Domain-Containing 3 (PNPLA3) NAFLD" and Insulin Sensitivity}

Approximately $30 \%$ of Europids and several other ethnic groups carry the PNPLA3 I148M variant [12]. The association between the PNPLA3 gene variant and NAFLD [12] has been replicated in over 50 studies, including eight genome wide association studies [71-73]. In a meta-analysis carriers of the I148M variant had $73 \%$ more liver fat, a 3.2-fold higher risk of necro-inflammation and a 3.2-fold greater risk of developing fibrosis than the non-carriers [71]. In a meta-analysis comprising 12 Asian studies, the risk of NAFLD was 1.9-fold increased in carriers compared to non-carriers [72]. Recent meta-analyses have also shown that this gene variant increases the risk of cirrhosis by 1.9-fold [74] and hepatocellular carcinoma (HCC) by 1.8-fold [75].

In vitro, the PNPLA3 I148M gene variant abolishes intrahepatocellular lipolysis [76,77] and by acting as a lysophosphatidic acid acyl transferase stimulates triglyceride synthesis from long unsaturated fatty acids containing coenzyme A (CoA) more than from saturated fatty acid CoAs [78]. The contribution of each these mechanisms to function of the PNPLA3 gene variant in the human 
liver is uncertain. It is clear, however, that the human liver lipidome markedly differs between "Obese/Metabolic NAFLD" and "PNPLA3 NAFLD" [14]. The increase in liver fat in the carriers of the PNPLA3 I148M gene variant is due to polyunsaturated triglycerides, whereas in "Obese/Metabolic NAFLD" the concentration of saturated triglycerides and insulin resistance-inducing ceramides is increased [14].

Table 2 summarizes the 14 studies that include data on insulin sensitivity in carriers and non-carriers of the I148M variant [12,79-91]. Carriers of the PNPLA3 I148M variant had more liver fat in their liver than non-carriers. Insulin sensitivity as evaluated by HOMA-IR [62], the hyperinsulinemic clamp technique, fasting or post-glucose insulin and glucose concentrations did not, however, differ between carriers and non-carriers of the gene variant. These studies included obese and non-obese, diabetic and non-diabetic as well as pediatric cohorts. Serum triglycerides were either similar or lower in variant allele carriers as compared to non-carriers, consistent with lack of insulin resistance (Table 2).

\section{3. "Transmembrane 6 Superfamily Member 2 (TM6SF2) NAFLD" and Insulin Sensitivity}

Approximately 7\% of all subjects carry the TM6SF2 E167K variant. This gene variant increases the risk of NAFLD, independent of genetic variation in PNPLA3 at rs738409, obesity and alcohol intake [92]. A recent meta-analysis reported that carriers of the TM6SF2 E167K gene variant have a 2.1-fold higher risk of NAFLD than non-carriers [93]. They also had lower circulating total and low density lipoprotein (LDL) cholesterol, and triglyceride concentrations than non-carriers [93].

Four in vitro studies have examined the mechanism by which the TM6SF2 E167K gene variant could increase liver fat. Recombinant adeno-associated viral vectors expressing short hairpin RNAs were used to reduce Tm6sf2 transcripts in the mouse liver, which increased hepatic triglyceride content three-fold [92]. TM6SF2 knock-out mice developed hepatic steatosis and had a three-fold reduced plasma VLDL triglyceride levels due to decreased lipidation [94]. In another study, TM6SF2 small interfering RNA inhibition also decreased export of triglyceride-rich lipoproteins and lipid droplet content in human hepatoma cell lines (Huh7 and HepG2) [95]. Overexpression of TM6SF2 in Huh7 cells reduced cellular triglyceride content [96]. Transient overexpression of human TM6SF2 in mice using a liver-targeting adenovirus containing the human TM6SF2 coding region increased, while knockdown of endogenous TM6SF2 decreased circulating total cholesterol [96]. In the latter study, no change in hepatic fat content was observed. This was hypothetized to be due to the transient exposure, compared to the lifetime exposure of humans carrying the gene variant [96].

Table 3 summarizes seven studies that have reported data on liver fat content and insulin sensitivity in carriers and non-carriers of TM6SF2 E167K gene variant $[13,81,92,97-100]$. In all but one of these studies, carriers had a significantly higher liver fat content as determined by ${ }^{1} \mathrm{H}-\mathrm{MRS}, \mathrm{MRI}$, histology or US $[13,92,97-100]$ than non-carriers. Insulin sensitivity, as determined by HOMA-IR or from oral glucose tolerance test measures did not differ between carriers and non-carriers. Triglyceride concentrations were either lower $[81,98,100]$ or similar $[13,97,99]$ but also in one study higher $[92]$ in TM6SF2 E167K variant allele carriers compared to non-carriers. 
Table 2. Insulin sensitivity in studies comparing liver fat between PNPLA3 I148M carriers and non-carriers.

\begin{tabular}{|c|c|c|c|c|c|c|c|c|c|c|c|c|c|}
\hline \multirow{2}{*}{ Cohort } & \multirow{2}{*}{$N$} & \multicolumn{3}{|c|}{ BMI $\left(\mathrm{kg} / \mathrm{m}^{2}\right)$} & \multicolumn{3}{|c|}{ Liver Fat } & \multicolumn{3}{|c|}{ Insulin Sensitivity (HOMA-IR) } & \multicolumn{3}{|c|}{$S$-Triglycerides $(\mathrm{mmol} / \mathrm{L})$} \\
\hline & & $\mathrm{I} 148^{\mathrm{II}}$ & $\mathrm{I}^{148} 8^{\mathrm{IM}}$ & $\mathrm{I} 148^{\mathrm{MM}}$ & $\mathrm{I}_{148} \mathrm{II}^{\mathrm{II}}$ & $\mathrm{I} 148^{\mathrm{IM}}$ & $\mathrm{I} 148^{\mathrm{MM}}$ & I148 ${ }^{\mathrm{II}}$ & $\mathrm{I}^{1488^{\mathrm{IM}}}$ & $\mathrm{I} 148^{\mathrm{MM}}$ & I148 ${ }^{\mathrm{II}}$ & $\mathrm{I}^{\mathrm{I} 48^{\mathrm{IM}}}$ & $\mathrm{I} 148^{\mathrm{MM}}$ \\
\hline \multirow{3}{*}{ Multiethnic ${ }^{1}[12]$} & \multirow{3}{*}{2111} & 30.4 & 31.1 & 30.0 & $3.7 \%{ }^{a}$ & $4.6 \%{ }^{a}$ & $7.7 \% * * *, \mathrm{a}$ & 3.3 & 3.5 & 3.3 & 1.32 & 1.35 & 1.41 \\
\hline & & 31.6 & 32.0 & 32.2 & $3.1 \%$ & $4.8 \%$ & $4.8 \%$ *** & 3.3 & 3.3 & 4.4 & 0.97 & 0.97 & 1.02 \\
\hline & & 29.2 & 28.8 & 28.8 & $3.5 \%$ & $3.7 \%$ & $3.5 \% * * *$ & 2.3 & 2.4 & 2.0 & 1.25 & 1.21 & 0.90 \\
\hline Germany [79] & 330 & 29.9 & 29.1 & 28.7 & $5.4 \%^{a}$ & $6.0 \%^{a}$ & $7.2 \% * * *, \mathrm{a}$ & $12.6^{\mathrm{v}, \mathrm{z}}$ & $12.9^{v, z}$ & $12.9^{\mathrm{v}, \mathrm{z}}$ & NA & NA & NA \\
\hline Finnish [80] & 291 & 30.5 & 30.0 & 32.2 & $9.0 \%{ }^{a}$ & $10.4 \% *$ a & $14.1 \% * *, \mathrm{a}$ & $72^{y, z}$ & $70 \mathrm{y}, \mathrm{z}$ & $74^{y, z}$ & 1.82 & 1.60 & 1.52 \\
\hline British [81] & 98 & 34.6 & 33.2 & 31.7 & $26.7 \%^{a}$ & $28.8 \%^{a}$ & $33.5 \%{ }^{a}$ & 2.4 & 3.1 & 2.6 & 1.60 & 1.70 & 1.40 \\
\hline Multiethnic $^{2}$ [82] & 1214 & $\mathrm{NA}^{\times}$ & $\mathrm{NA}^{\times}$ & NA $\times$ & $\begin{array}{c}57^{\mathrm{b}} \\
55\end{array}$ & $\begin{array}{c}55^{\mathrm{b}} \\
51\end{array}$ & $\begin{array}{c}46^{* * *, b} \\
47^{* * *}\end{array}$ & $\mathrm{NA}^{\times}$ & $\mathrm{NA}^{\times}$ & $\mathrm{NA}^{\times}$ & NA $\times$ & NA $\times$ & $\mathrm{NA}^{\times}$ \\
\hline Dutch [83] & 470 & 37.7 & 37.6 & 37.6 & $66 \%^{c}$ & $78 \%^{c}$ & $100 \% * * *, \mathrm{c}$ & 2.7 & 2.8 & 2.9 & 1.42 & 1.47 & 1.46 \\
\hline Italian [84] & 61 & 25.7 & \multicolumn{2}{|c|}{25.9} & $16 \%{ }^{d}$ & \multicolumn{2}{|c|}{$32 \% *, d$} & 3.4 & \multicolumn{2}{|c|}{4.7} & 1.13 & \multicolumn{2}{|c|}{1.15} \\
\hline Italian [85] & 253 & 30.7 & 30.7 & 29.8 & $44 \%^{c}$ & $48 \%^{c}$ & $63 \% * *, c$ & 3.9 & 4 & 5.2 & 1.64 & 1.85 & 1.79 \\
\hline Italian [86] & 211 & 32.1 & 30.4 & 31.7 & $4^{\mathrm{e}}$ & $4^{\mathrm{e}}$ & $4^{\mathrm{e}}$ & 3.5 & 3.5 & 2.8 & 1.77 & 1.59 & $1.26^{* *}$ \\
\hline Taiwanese [87] & 879 & 23.3 & 23.6 & 23.6 & $13 \% \mathrm{f}$ & $19 \% \mathrm{f}$ & $23 \% *, f$ & 1.4 & 1.5 & 1.5 & 1.11 & 1.16 & $1.38 *$ \\
\hline South Korean [88] & 1363 & 24.7 & 24.4 & $23.9^{* *}$ & $38 \% \mathrm{f}$ & $45 \%{ }^{\mathrm{f}}$ & $54 \% *, \mathrm{f}$ & 2.3 & 2.1 & $1.6^{* *}$ & 1.54 & 1.38 & $1.31^{* *}$ \\
\hline Taiwanese, pediatric [89] & 520 & 26.3 & 26.2 & 25.9 & $21 \% \mathrm{f}$ & $13 \%{ }^{f}$ & $30 \% * *, \mathrm{f}$ & 2.4 & 2.5 & 1.7 & 1.11 & 1.03 & 0.94 \\
\hline Italian, pediatric [90] & 475 & NA & NA & NA & $13 \% \mathrm{f}$ & $19 \%{ }^{\mathrm{f}}$ & $41 \% *, \mathrm{f}$ & 3.3 & 3.0 & 3.0 & 0.56 & 0.56 & 0.53 \\
\hline Italian, pediatric [91] & 149 & $95.2^{\circ}$ & $95.0^{\circ}$ & $94.1^{\circ}$ & $\begin{array}{c}70 \% \mathrm{~g} \\
30 \% \\
0 \%\end{array}$ & $\begin{array}{l}7 \% \mathrm{~g} \\
78 \% \\
15 \%\end{array}$ & $\begin{array}{c}4^{*}{ }^{* * *, g} \\
4 \% \\
92 \%\end{array}$ & 2.5 & 2.7 & 2.4 & 1.28 & 1.19 & 1.39 \\
\hline
\end{tabular}

BMI, body mass index; CT, computed tomography; HOMA-IR, Homeostasis model assessment of insulin resistance [62]; HU, Houndsfield Unit; MRI, magnetic resonance imaging; NA, not available; OGTT, oral glucose tolerance test; US, ultrasound. ${ }^{*}$ Significant difference between groups in ANOVA or $t$ test. ${ }^{*} p<0.05$; ${ }^{* *} p<0.01,{ }^{* * *} p<0.0001$. Data are presented as mean or median. ${ }^{1}$ Caucasian, African and Hispanic Americans; ${ }^{2}$ Hispanic and African Americas. ${ }^{\circ}$ BMI centiles; ${ }^{1}{ }^{1} \mathrm{H}-\mathrm{MRS}$ (liver fat content, $\%$ ); ${ }^{\mathrm{b}} \mathrm{CT}$ (liver density, HU);

${ }^{\mathrm{c}}$ Histology (prevalence of steatosis, \%); ${ }^{\mathrm{d}}$ Histology (\% hepatocytes steatotic); ${ }^{\mathrm{e}}$ US (severity of steatosis by Hamaguchi score, $3-4=$ moderate); ${ }^{\mathrm{f}}$ US (prevalence of steatosis, $\%$ );

${ }^{\mathrm{g}}$ Histology (severity of steatosis, grade 1/2/3); ${ }^{\mathrm{v}}$ OGTT (arbitrary unit); ${ }^{\mathrm{y}}$ fasting serum insulin (pmol/L); ${ }^{\mathrm{z}}$ hyperinsulinemic clamp was also performed, data not shown in the table;

$\times$ Data not shown, but it was reported that genetic variation at rs738409 did not correlate with HOMA-IR, insulin sensitivity index, BMI or S-triglycerides. 
Table 3. Insulin sensitivity in studies comparing liver fat between TM6SF2 E167K carriers and non-carriers.

\begin{tabular}{|c|c|c|c|c|c|c|c|c|c|}
\hline \multirow{2}{*}{ Cohort } & \multirow{2}{*}{$N$} & \multicolumn{2}{|c|}{ BMI $\left(\mathrm{kg} / \mathrm{m}^{2}\right)$} & \multicolumn{2}{|c|}{ Liver Fat } & \multicolumn{2}{|c|}{ Insulin Sensitivity (HOMA-IR) } & \multicolumn{2}{|c|}{$S$-Triglycerides $(\mathrm{mmol} / \mathrm{L})$} \\
\hline & & EE & $\mathrm{EK}+\mathrm{KK}$ & EE & $\mathbf{E K}+\mathbf{K K}$ & $\mathrm{EE}$ & $\mathrm{EK}+\mathrm{KK}$ & $\mathrm{EE}$ & $\mathbf{E K}+\mathbf{K K}$ \\
\hline Multiethnic ${ }^{1}$ [92] & 4587 & 29.6 & $28.5 / 31.8$ & $3.5 \%{ }^{a}$ & $4.4 \% / 15.7 \% * * *, \mathrm{a}$ & 3.0 & $2.9 / 4.6$ & 1.39 & $1.33 / 1.47^{*}$ \\
\hline Finns [97] & 300 & 33.7 & 32.5 & $6.8 \%{ }^{a}$ & $11.2 \% *$ a & 3.0 & 2.9 & 1.40 & 1.50 \\
\hline British [81] & 98 & 32.6 & 35.4 & $28.5 \%^{\mathrm{a}}$ & $29.0 \%^{a}$ & 2.7 & 4.0 & 1.60 & $1.50 *$ \\
\hline Argentineans [13] & 361 & 29.8 & 30.2 & NA & NA & 3.1 & 3.0 & 1.87 & 1.31 \\
\hline Multiethnic $^{2}$ [98] & 502 & 32.2 & $31.2 / 30.8$ & $\begin{array}{l}\text { S0: } 3 \% \text { b } \\
\text { S1: } 50 \% \\
\text { S2: } 27 \% \\
\text { S3: } 20 \%\end{array}$ & $\begin{array}{c}\text { S0: } 0 \% / 0 \% \text { b } \\
\text { S1: } 35 \% / 45 \% \\
\text { S2: } 40 \% / 20 \% \\
\text { S3: } 25 \% / 35 \% \text { * }\end{array}$ & 3.5 & $2.8 / 2.8$ & 1.70 & $1.36 / 1.08^{* *}$ \\
\hline Multiethnic ${ }^{1}$, pediatric [99] & $957^{\wedge}$ & 33.0 & 32.6 & $6.7 \%{ }^{\mathrm{c} \wedge}$ & $11.1 \% * *, \mathrm{c}, \wedge$ & $1.9^{x}$ & $2.0^{x}$ & 1.20 & 1.21 \\
\hline Italian, pediatric [100] & 1010 & $2.9^{\circ}$ & $2.9^{\circ}$ & $47 \% \mathrm{~d}$ & $89 \% * *, \mathrm{~d}$ & 5.6 & 4.6 & 1.12 & $1.02 *$ \\
\hline
\end{tabular}

BMI, body mass index; BMI-SDS, body mass index standard deviation score; HOMA-IR, Homeostasis model assessment of insulin resistance [62]; MRI-PDFF, magnetic resonance imaging-measured proton density fat fraction; NA, not available; OGTT, oral glucose tolerance test; US, ultrasound; WBISI, whole body insulin sensitivity index. Significant difference between groups in ANOVA or $t$ test, ${ }^{*} p<0.05 ;{ }^{* *} p<0.01 ; * * *<0.0001$. Data are presented as mean or median. ${ }^{1}$ Caucasian, African and Hispanic Americans; ${ }^{2}$ Caucasian, Asian, Hispanic; International Liver Disease Genetics Consortium; ${ }^{\wedge}$ Liver fat content available on 454 subjects, BMI, insulin sensitivity and $S$-triglycerides on 957 subjects; ${ }^{\circ}$ BMI-SDS; ${ }^{a}{ }^{1}$ H-MRS (liver fat content, $\left.\%\right) ;{ }^{b}$ Histology, prevalence of each steatosis grade; ${ }^{\mathrm{c}}$ MRI-PDFF, liver fat, $\%$, $(n=454) ;{ }^{\mathrm{d}}$ US (prevalence of steatosis, $\left.\%\right) ;{ }^{\mathrm{x}}$ OGTT (WBISI). 


\section{Materials and Methods}

We performed a systematic search using PubMed and Medline on two topics. For definitions of normal liver fat, we used the following search terms and their combinations: "normal liver fat", "liver histology", "liver biopsy" and "liver triglycerides", "liver H-MRS", "liver MRI", "liver MRI-PDFF", "liver CT", "liver ultrasound" and received 526 matches. Thirty-three studies included data on normal liver fat content or compared liver fat measured using different techniques. To review the association between insulin resistance and genetic NAFLD, we searched for studies using the following search terms: "PNPLA3" or "TM6SF2" and "insulin resistance", "euglycemic (hyperinsulinemic) clamp", "fasting glucose", "fasting insulin", "HOMA-IR", "oral glucose tolerance test" and included studies which compared results between carriers and non-carriers of PNPLA3 I148M or TM6SF2 E167K gene variants. A total of 124 matched were found. Of these, 22 studies were informative with respect to liver fat content and insulin resistance between genotypes, and were thus included.

\section{Conclusions}

Normal liver fat content based on liver histology can be defined as macroscopic steatosis in less than $5 \%$ of hepatocytes. With ${ }^{1} \mathrm{H}$-MRS, normal liver fat in the population-based DHS was defined as less or equal than $5.56 \%$ [23], which corresponds to histologic liver fat of approximately $15 \%$ [31,32]. Definitions of normal liver fat content thus depend on the method used. There is also no prospective evidence that these normal values are of clinical relevance with respect to the development of liver fibrosis.

Although NAFLD has often been regarded simply as the hepatic manifestation of the MetS, it is now clear that NAFLD is heterogeneous. While "Obese/Metabolic NAFLD" is associated with NAFLD and features of the MetS and an increased risk of type 2 diabetes and cardiovascular disease, NAFLD caused by I148M variant in PNPLA3 and the E167K variant in TM6SF2 is not accompanied by insulin resistance. Thus, lack of insulin resistance does not exclude NAFLD and not all patients with NAFLD are at increased risk of type 2 diabetes and cardiovascular disease. Given that both the MetS and the genetic variants in PNPLA3 and TM6SF2 are common, there are also many individuals with "double trouble NAFLD" [14].

\section{Future Research and Uncertainties}

Although NAFL defined as macroscopic steatosis affecting $>5 \%$ of hepatocytes predicts fibrosis [7-9], it is unknown how various degrees of steatosis predict liver outcomes. Such information would help the clinician to decide which patients to refer to the hepatologist. The same applies to the non-invasive markers of NAFL proposed to be used by the recent European NAFLD guideline if imaging tools are not available [101]. This guideline also recommended testing for the I148M gene variant in "selected cases and in clinical trials". The latter might be helpful in identifying patients with NAFLD who are at risk for advanced liver disease but who lack features of the MetS and are therefore not at risk for cardiovascular disease or type 2 diabetes. A cost-benefit analysis of this suggestion is warranted.

Acknowledgments: This study was supported by research grants from the Academy of Finland (Hannele Yki-Järvinen), EU H2020 EPoS 634413 (Hannele Yki-Järvinen), the Sigrid Juselius (Hannele Yki-Järvinen), State Research Funding (EVO) (Hannele Yki-Järvinen), the Novo Nordisk (Hannele Yki-Järvinen) Foundations and personal grants from the Finnish Medical Association (Elina M. Petäjä) and the Paulo Foundation (Elina M. Petäjä).

Author Contributions: Elina M. Petäjä and Hannele Yki-Järvinen have reviewed the literature and written the review.

Conflicts of Interest: The authors declare no conflict of interest. 


$\begin{array}{ll}\text { Abbreviations } & \text { proton magnetic resonance spectroscopy } \\ { }^{1} \text { H-MRS } & \text { alanine aminotransferase } \\ \text { ALT } & \text { aspartate aminotransferase } \\ \text { AST } & \text { body mass index } \\ \text { BMI } & \text { body mass index standard deviation score } \\ \text { BMI-SDS } & \text { coronary heart disease } \\ \text { CHD } & \text { coenzyme A } \\ \text { CoA } & \text { computed tomography } \\ \text { CT } & \text { diabetes mellitus } \\ \text { DM } & \text { Dallas Heart Study } \\ \text { DHS } & \text { free fatty acids } \\ \text { FFA } & \text { fasting serum } \\ \text { fS } & \text { high density lipoprotein } \\ \text { HDL } & \text { monocyte chemoattractant protein-1 } \\ \text { MCP-1 } & \text { hepatocellular carcinoma } \\ \text { HCC } & \text { high density lipoprotein } \\ \text { HDL } & \text { homeostasis model assessment for insulin resistance } \\ \text { HOMA-IR } & \text { low density lipoprotein } \\ \text { LDL } & \text { metabolic syndrome } \\ \text { MetS } & \text { magnetic resonance imaging } \\ \text { MRI } & \text { non-alcoholic fatty liver } \\ \text { NAFL } & \text { non-alcoholic fatty liver disease } \\ \text { NAFLD } & \text { non-alcoholic steatohepatitis } \\ \text { NASH } & \text { oral glucose tolerance test } \\ \text { OGTT } & \text { plasma } \\ \text { P } & \text { proton density fat fraction } \\ \text { PDFF } & \text { patatin-like phospholipase domain-containing 3 } \\ \text { PNPLA3 } & \text { transmembrane 6 superfamily member 2 } \\ \text { TM6SF2 } & \text { tumor necrosis factor- } \alpha \\ \text { TNF- } \alpha & \text { ultrasound } \\ \text { US } & \text { very low density lipoprotein } \\ \text { VLDL } & \\ & \end{array}$

\section{References}

1. Chalasani, N.; Younossi, Z.; Lavine, J.E.; Diehl, A.M.; Brunt, E.M.; Cusi, K.; Charlton, M.; Sanyal, A.J. The diagnosis and management of non-alcoholic fatty liver disease: Practice guideline by the American Association for the Study of Liver Diseases, American College of Gastroenterology, and the American Gastroenterological Association. Am. J. Gastroenterol. 2012, 107, 811-826. [CrossRef] [PubMed]

2. Neuschwander-Tetri, B.A. Hepatic lipotoxicity and the pathogenesis of nonalcoholic steatohepatitis: The central role of nontriglyceride fatty acid metabolites. Hepatology 2010, 52, 774-788. [CrossRef] [PubMed]

3. Brunt, E.M.; Kleiner, D.E.; Wilson, L.A.; Belt, P.; Neuschwander-Tetri, B.A. The NAS and the histopathologic diagnosis in NAFLD: Distinct clinicopathologic meanings. Hepatology 2011, 53, 810-820. [CrossRef] [PubMed]

4. Anstee, Q.M.; Day, C.P. Progression of NAFLD to diabetes mellitus, cardiovascular disease or cirrhosis. Nat. Rev. Gastroenterol. Hepatol. 2013, 10, 330-344. [CrossRef] [PubMed]

5. Angulo, P.; Kleiner, D.E.; Dam-Larsen, S.; Adams, L.A.; Bjornsson, E.S.; Charatcharoenwitthaya, P.; Mills, P.R.; Keach, J.C.; Lafferty, H.D.; Stahler, A.; et al. Liver fibrosis, but no other histologic features, is associated with long-term outcomes of patients with nonalcoholic fatty liver disease. Gastroenterology 2015, 149, 389-397. [CrossRef] [PubMed] 
6. Ekstedt, M.; Hagstrom, H.; Nasr, P.; Fredrikson, M.; Stal, P.; Kechagias, S.; Hultcrantz, R. Fibrosis stage is the strongest predictor for disease-specific mortality in NAFLD after up to 33 years of follow-up. Hepatology 2015, 61, 1547-1554. [CrossRef] [PubMed]

7. McPherson, S.; Hardy, T.; Henderson, E.; Burt, A.D.; Day, C.P.; Anstee, Q.M. Evidence of NAFLD progression from steatosis to fibrosing-steatohepatitis using paired biopsies: Implications for prognosis and clinical management. J. Hepatol. 2015, 62, 1148-1155. [CrossRef] [PubMed]

8. Pais, R.; Charlotte, F.; Fedchuk, L.; Bedossa, P.; Lebray, P.; Poynard, T.; Ratziu, V.; LIDO Study Group. A systematic review of follow-up biopsies reveals disease progression in patients with non-alcoholic fatty liver. J. Hepatol. 2013, 59, 550-556. [CrossRef] [PubMed]

9. Wong, V.W.-S.; Wong, G.L.-H.; Choi, P.C.-L.; Chan, A.W.-H.; Li, M.K.-P.; Chan, H.-Y.; Chim, A.M.-L.; Yu, J.; Sung, J.J.-Y.; Chan, H.L.-Y. Disease progression of non-alcoholic fatty liver disease: A prospective study with paired liver biopsies at 3 years. Gut 2010, 59, 969-974. [CrossRef] [PubMed]

10. Tarantino, G.; Conca, P.; Riccio, A.; Tarantino, M.; di Minno, M.N.; Chianese, D.; Pasanisi, F.; Contaldo, F.; Scopacasa, F.; Capone, D. Enhanced serum concentrations of transforming growth factor-beta1 in simple fatty liver: Is it really benign? J. Transl. Med. 2008, 6. [CrossRef] [PubMed]

11. Yki-Järvinen, H. Non-alcoholic fatty liver disease as a cause and a consequence of metabolic syndrome. Lancet Diabetes Endocrinol. 2014, 2, 901-910. [CrossRef]

12. Romeo, S.; Kozlitina, J.; Xing, C.; Pertsemlidis, A.; Cox, D.; Pennacchio, L.A.; Boerwinkle, E.; Cohen, J.C.; Hobbs, H.H. Genetic variation in PNPLA3 confers susceptibility to nonalcoholic fatty liver disease. Nat. Genet. 2008, 40, 1461-1465. [CrossRef] [PubMed]

13. Sookoian, S.; Castaño, G.O.; Scian, R.; Mallardi, P.; Fernández Gianotti, T.; Burgueño, A.L.; San Martino, J.; Pirola, C.J. Genetic variation in transmembrane 6 superfamily member 2 and the risk of nonalcoholic fatty liver disease and histological disease severity. Hepatology 2015, 61, 515-525. [CrossRef] [PubMed]

14. Luukkonen, P.K.; Zhou, Y.; Sädevirta, S.; Leivonen, M.; Arola, J.; Orešič, M.; Hyötyläinen, T.; Yki-Järvinen, H. Hepatic ceramides dissociate steatosis and insulin resistance in patients with non-alcoholic fatty liver disease. J. Hepatol. 2016, 64, 1167-1175. [CrossRef] [PubMed]

15. Donhoffer, H. Quantitative estimation of lipids in needle biopsy sized specimens of cadaver liver. Acta Med. Acad. Sci. Hung 1974, 31, 47-49. [PubMed]

16. Hoyumpa, D.A.M., Jr.; Greene, H.L.; Dunn, G.D.; Schenker, S. Fatty liver: Biochemical and clinical considerations. Dig. Dis. Sci. 1975, 20, 1142-1170. [CrossRef]

17. Kleiner, D.E.; Brunt, E.M.; van Natta, M.; Behling, C.; Contos, M.J.; Cummings, O.W.; Ferrell, L.D.; Liu, Y.-C.; Torbenson, M.S.; Unalp-Arida, A.; et al. Nonalcoholic steatohepatitis clinical research network design and validation of a histological scoring system for nonalcoholic fatty liver disease. Hepatology 2005, 41, 1313-1321. [CrossRef] [PubMed]

18. Brunt, E.M.; Tiniakos, D.G. Histopathology of nonalcoholic fatty liver disease. World J. Gastroenterol. 2010, 16, 5286-5296. [CrossRef] [PubMed]

19. Bedossa, P.; Poitou, C.; Veyrie, N.; Bouillot, J.-L.; Basdevant, A.; Paradis, V.; Tordjman, J.; Clément, K. Histopathological algorithm and scoring system for evaluation of liver lesions in morbidly obese patients. Hepatology 2012, 56, 1751-1759. [CrossRef] [PubMed]

20. Korenblat, K.M.; Fabbrini, E.; Mohammed, B.S.; Klein, S. Liver, muscle, and adipose tissue insulin action is directly related to intrahepatic triglyceride content in obese subjects. Gastroenterology 2008, 134, 1369-1375. [CrossRef] [PubMed]

21. Laurell, S.; Lundquist, A. Lipid composition of human liver biopsy specimens. Acta Med. Scand. 1971, 189, 65-68. [CrossRef] [PubMed]

22. Piekarski, J.; Goldberg, H.I.; Royal, S.A.; Axel, L.; Moss, A.A. Difference between liver and spleen CT numbers in the normal adult: Its usefulness in predicting the presence of diffuse liver disease. Radiology 1980, 137, 727-729. [CrossRef] [PubMed]

23. Szczepaniak, L.S.; Nurenberg, P.; Leonard, D.; Browning, J.D.; Reingold, J.S.; Grundy, S.; Hobbs, H.H.; Dobbins, R.L. Magnetic resonance spectroscopy to measure hepatic triglyceride content: Prevalence of hepatic steatosis in the general population. Am. J. Physiol. Endocrinol. Metab. 2005, 288, E462-E468. [CrossRef] [PubMed] 
24. Petersen, K.F.; Dufour, S.; Feng, J.; Befroy, D.; Dziura, J.; Dalla Man, C.; Cobelli, C.; Shulman, G.I. Increased prevalence of insulin resistance and nonalcoholic fatty liver disease in Asian-Indian men. Proc. Natl. Acad. Sci. USA 2006, 103, 18273-18277. [CrossRef] [PubMed]

25. Fishbein, M.H.; Gardner, K.G.; Potter, C.J.; Schmalbrock, P.; Smith, M.A. Introduction of fast MR imaging in the assessment of hepatic steatosis. Magn. Reson. Imaging 1997, 15, 287-293. [CrossRef]

26. Joseph, A.E.A.; Dewbury, K.C.; McGuire, P.G. Ultrasound in the detection of chronic liver disease (the "bright liver"). Br. J. Radiol. 1978, 52, 184-188. [CrossRef] [PubMed]

27. Saverymuttu, S.H.; Joseph, A.E.; Maxwell, J.D. Ultrasound scanning in the detection of hepatic fibrosis and steatosis. Br. Med. J. (Clin. Res. Ed.) 1986, 292, 13-15. [CrossRef]

28. Bohte, A.E.; van Werven, J.R.; Bipat, S.; Stoker, J. The diagnostic accuracy of US, CT, MRI and 1H-MRS for the evaluation of hepatic steatosis compared with liver biopsy: A meta-analysis. Eur. Radiol. 2011, 21, 87-97. [CrossRef] [PubMed]

29. Longo, R.; Ricci, C.; Masutti, F.; Vidimari, R.; Crocé, L.S.; Bercich, L.; Tiribelli, C.; Dalla Palma, L. Fatty infiltration of the liver: Quantification by $1 \mathrm{H}$ localized magnetic resonance spectroscopy and comparison with computed tomography. Investig. Radiol. 1993, 28, 297-302. [CrossRef]

30. Szczepaniak, L.S.; Babcock, E.E.; Schick, F.; Dobbins, R.L.; Garg, A.; Burns, D.K.; McGarry, J.D.; Stein, D.T. Measurement of intracellular triglyceride stores by $\mathrm{H}$ spectroscopy: Validation in vivo. Am. J. Physiol. Endocrinol. Metab. 1999, 276, E977-E989.

31. Kotronen, A.; Vehkavaara, S.; Seppälä-Lindroos, A.; Bergholm, R.; Yki-Järvinen, H. Effect of liver fat on insulin clearance. Am. J. Physiol. Endocrinol. Metab. 2007, 293, E1709-E1715. [CrossRef] [PubMed]

32. Cowin, G.J.; Jonsson, J.R.; Bauer, J.D.; Ash, S.; Ali, A.; Osland, E.J.; Purdie, D.M.; Clouston, A.D.; Powell, E.E.; Galloway, G.J. Magnetic resonance imaging and spectroscopy for monitoring liver steatosis. J. Magn. Reson. Imaging 2008, 28, 937-945. [CrossRef] [PubMed]

33. Noureddin, M.; Lam, J.; Peterson, M.R.; Middleton, M.; Hamilton, G.; Le, T.-A.; Bettencourt, R.; Changchien, C.; Brenner, D.A.; Sirlin, C.; et al. Utility of magnetic resonance imaging versus histology for quantifying changes in liver fat in nonalcoholic fatty liver disease trials. Hepatology 2013, 58, 1930-1940. [CrossRef] [PubMed]

34. Thomsen, C.; Becker, U.; Winkler, K.; Christoffersen, P.; Jensen, M.; Henriksen, O. Quantification of liver fat using magnetic resonance spectroscopy. Magn. Reson. Imaging 1994, 12, 487-495. [CrossRef]

35. Dixon, W.T. Simple proton spectroscopic imaging. Radiology 1984, 153, 189-194. [CrossRef] [PubMed]

36. Rofsky, N.M.; Weinreb, J.C.; Ambrosino, M.M.; Safir, J.; Krinsky, G. Comparison between in-phase and opposed-phase T1-weighted breath-hold FLASH sequences for hepatic imaging. J. Comput. Assist. Tomogr. 1996, 20, 230-235. [CrossRef] [PubMed]

37. Cassidy, F.H.; Yokoo, T.; Aganovic, L.; Hanna, R.F.; Bydder, M.; Middleton, M.S.; Hamilton, G.; Chavez, A.D.; Schwimmer, J.B.; Sirlin, C.B. Fatty liver disease: MR Imaging techniques for the detection and quantification of liver steatosis1. Radiographics 2009, 29, 231-260. [CrossRef] [PubMed]

38. Hussain, H.K.; Chenevert, T.L.; Londy, F.J.; Gulani, V.; Swanson, S.D.; McKenna, B.J.; Appelman, H.D.; Adusumilli, S.; Greenson, J.K.; Conjeevaram, H.S. Hepatic fat fraction: MR imaging for quantitative measurement and display-Early experience 1. Radiology 2005, 237, 1048-1055. [CrossRef] [PubMed]

39. Fishbein, M.H.; Stevens, W.R. Rapid MRI using a modified Dixon technique: A non-invasive and effective method for detection and monitoring of fatty metamorphosis of the liver. Pediatr. Radiol. 2001, 31, 806-809. [CrossRef] [PubMed]

40. Hines, C.D.G.; Frydrychowicz, A.; Hamilton, G.; Tudorascu, D.L.; Vigen, K.K.; Yu, H.; McKenzie, C.A.; Sirlin, C.B.; Brittain, J.H.; Reeder, S.B. $\mathrm{T}_{1}$ independent, $\mathrm{T}_{2}{ }^{*}$ corrected chemical shift based fat-water separation with multi-peak fat spectral modeling is an accurate and precise measure of hepatic steatosis. J. Magn. Reson. Imaging 2011, 33, 873-881. [CrossRef] [PubMed]

41. Meisamy, S.; Hines, C.D.G.; Hamilton, G.; Sirlin, C.B.; McKenzie, C.A.; Yu, H.; Brittain, J.H.; Reeder, S.B. Quantification of hepatic steatosis with T1-independent, T2*-corrected MR imaging with spectral modeling of fat: blinded comparison with MR spectroscopy. Radiology 2011, 258, 767-775. [CrossRef] [PubMed]

42. Kang, G.H.; Cruite, I.; Shiehmorteza, M.; Wolfson, T.; Gamst, A.C.; Hamilton, G.; Bydder, M.; Middleton, M.S.; Sirlin, C.B. Reproducibility of MRI-determined proton density fat fraction across two different MR scanner platforms. J. Magn. Reson. Imaging 2011, 34, 928-934. [CrossRef] [PubMed] 
43. Permutt, Z.; Le, T.A.; Peterson, M.R.; Seki, E.; Brenner, D.A.; Sirlin, C.; Loomba, R. Correlation between liver histology and novel magnetic resonance imaging in adult patients with non-alcoholic fatty liver disease-MRI accurately quantifies hepatic steatosis in NAFLD. Aliment. Pharmacol. Ther. 2012, 36, $22-29$. [CrossRef] [PubMed]

44. Patel, N.S.; Peterson, M.R.; Brenner, D.A.; Heba, E.; Sirlin, C.; Loomba, R. Association between novel MRI-estimated pancreatic fat and liver histology-determined steatosis and fibrosis in non-alcoholic fatty liver disease. Aliment. Pharmacol. Ther. 2013, 37, 630-639. [CrossRef] [PubMed]

45. Idilman, I.S.; Aniktar, H.; Idilman, R.; Kabacam, G.; Savas, B. Hepatic steatosis: Quantification by proton density fat fraction with MR imaging versus liver biopsy. Radiology 2013, 267, 767-775. [CrossRef] [PubMed]

46. Tang, A.; Tan, J.; Sun, M.; Hamilton, G.; Bydder, M.; Wolfson, T.; Gamst, A.C.; Middleton, M.; Brunt, E.M.; Loomba, R.; et al. Nonalcoholic fatty liver disease: MR imaging of liver proton density fat fraction to assess hepatic steatosis. Radiology 2013, 267, 422-431. [CrossRef] [PubMed]

47. Needleman, L.; Kurtz, A.B.; Rifkin, M.D.; Cooper, H.S.; Pasto, M.E.; Goldberg, B.B. Sonography of diffuse benign liver-disease-Accuracy of pattern-recognition and grading. Am. J. Roentgenol. 1986, 146, 1011-1015. [CrossRef] [PubMed]

48. Joseph, A.E.A.; Saverymuttu, S.H.; Al-Sam, S.; Cook, M.G.; Maxwell, J.D. Comparison of liver histology with ultrasonography in assessing diffuse parenchymal liver disease. Clin. Radiol. 1991, 43, 26-31. [CrossRef]

49. Foster, K.J.; Dewbury, K.C.; Griffith, A.H.; Wright, R. The accuracy of ultrasound in the detection of fatty infiltration of the liver. Br. J. Radiol. 1979, 53, 440-442. [CrossRef] [PubMed]

50. Mottin, C.C.; Moretto, M.; Padoin, A.V.; Swarowsky, A.M.; Toneto, M.G.; Glock, L.; Repetto, G. The role of ultrasound in the diagnosis of hepatic steatosis in morbidly obese patients. Obes. Surg. 2004, 14, 635-637. [CrossRef] [PubMed]

51. Ryan, C.K.; Johnson, L.A.; Germin, B.I.; Marcos, A. One hundred consecutive hepatic biopsies in the workup of living donors for right lobe liver transplantation. Liver Transpl. 2002, 8, 1114-1122. [CrossRef] [PubMed]

52. Bril, F.; Ortiz Lopez, C.; Lomonaco, R.; Orsak, B.; Freckleton, M.; Chintapalli, K.; Hardies, J.; Lai, S.; Solano, F.; Tio, F.; et al. Clinical value of liver ultrasound for the diagnosis of nonalcoholic fatty liver disease in overweight and obese patients. Liver Int. 2015, 35, 2139-2146. [CrossRef] [PubMed]

53. Hernaez, R.; Lazo, M.; Bonekamp, S.; Kamel, I.; Brancati, F.L.; Guallar, E.; Clark, J.M. Diagnostic accuracy and reliability of ultrasonography for the detection of fatty liver: A meta-analysis. Hepatology 2011, 54, 1082-1090. [CrossRef] [PubMed]

54. Xia, M.F.; Yan, H.M.; He, W.Y.; Li, X.M.; Li, C.L.; Yao, X.Z.; Li, R.K.; Zeng, M.S.; Gao, X. Standardized ultrasound hepatic/renal ratio and hepatic attenuation rate to quantify liver fat content: An improvement method. Obesity (Silver Spring) 2012, 20, 444-452. [CrossRef] [PubMed]

55. Loomba, R.; Sanyal, A.J. The global NAFLD epidemic. Nat. Rev. Gastroenterol. Hepatol. 2013, 10, 686-690. [CrossRef] [PubMed]

56. Wong, R.J.; Ahmed, A. Obesity and non-alcoholic fatty liver disease: Disparate associations among Asian populations. World J. Hepatol. 2014, 6, 263-273. [CrossRef] [PubMed]

57. Schwenzer, N.F.; Springer, F.; Schraml, C.; Stefan, N.; Machann, J.; Schick, F. Non-invasive assessment and quantification of liver steatosis by ultrasound, computed tomography and magnetic resonance. J. Hepatol. 2009, 51, 433-445. [CrossRef] [PubMed]

58. Bydder, G.M.; Chapman, R.W.G.; Harry, D.; Bassan, L.; Sherlock, S.; Kreel, L. Computed tomography attenuation values in fatty liver. J. Comput. Tomogr. 1981, 5, 33-35. [CrossRef]

59. Park, S.H.; Kim, P.N.; Kim, K.W.; Lee, S.W.; Yoon, S.E.; Park, S.W.; Ha, H.K.; Lee, M.-G.; Hwang, S.; Lee, S.-G.; et al. Macrovesicular hepatic steatosis in living liver donors: Use of CT for quantitative and qualitative assessment1. Radiology 2006, 239, 105-112. [CrossRef] [PubMed]

60. Kodama, Y.; Ng, C.S.; Wu, T.T.; Ayers, G.D.; Curley, S.A.; Abdalla, E.K.; Vauthey, J.N.; Charnsangavej, C. Comparison of CT methods for determining the fat content of the liver. AJR Am. J. Roentgenol. 2007, 188, 1307-1312. [CrossRef] [PubMed]

61. Seppälä-Lindroos, A.; Vehkavaara, S.; Häkkinen, A.-M.; Goto, T.; Westerbacka, J.; Sovijärvi, A.; Halavaara, J.; Yki-Järvinen, H. Fat accumulation in the liver is associated with defects in insulin suppression of glucose production and serum free fatty acids independent of obesity in normal men. J. Clin. Endocrinol. Metab. 2002, 87, 3023-3028. [CrossRef] [PubMed] 
62. Matthews, D.R.; Hosker, J.P.; Rudenski, A.S.; Naylor, B.A.; Treacher, D.F.; Turner, R.C. Homeostasis model assessment: Insulin resistance and beta-cell function from fasting plasma glucose and insulin concentrations in man. Diabetologia 1985, 28, 412-419. [CrossRef] [PubMed]

63. Kotronen, A.; Westerbacka, J.; Bergholm, R.; Yki-Järvinen, H. Liver fat in the metabolic syndrome. J. Clin. Endocrinol. Metab. 2007, 92, 3490-3497. [CrossRef] [PubMed]

64. Gastaldelli, A.; Kozakova, M.; Højlund, K.; Flyvbjerg, A.; Favuzzi, A.; Mitrakou, A.; Balkau, B. Fatty liver is associated with insulin resistance, risk of coronary heart disease, and early atherosclerosis in a large European population. Hepatology 2009, 49, 1537-1544. [CrossRef] [PubMed]

65. Donnelly, K.L.; Smith, C.I.; Schwarzenberg, S.J.; Jessurun, J.; Boldt, M.D.; Parks, E.J. Sources of fatty acids stored in liver and secreted via lipoproteins in patients with nonalcoholic fatty liver disease. J. Clin. Investig. 2005, 115, 1343-1351. [CrossRef] [PubMed]

66. Lambert, J.E.; Ramos-Roman, M.A.; Browning, J.D.; Parks, E.J. Increased de novo lipogenesis is a distinct characteristic of individuals with nonalcoholic fatty liver disease. Gastroenterology 2014, 146, 726-735. [CrossRef] [PubMed]

67. Kotronen, A.; Vehkavaara, S.; Yki-Järvinen, H. Increased liver fat, impaired insulin clearance, and hepatic and adipose tissue insulin resistance in type 2 diabetes. Gastroenterology 2008, 135, 122-130. [CrossRef] [PubMed]

68. Gastaldelli, A.; Cusi, K.; Pettiti, M.; Hardies, J.; Miyazaki, Y.; Berria, R.; Buzzigoli, E.; Sironi, A.M.; Cersosimo, E.; Ferrannini, E.; et al. Relationship between hepatic/visceral fat and hepatic insulin resistance in nondiabetic and type 2 diabetic subjects. Gastroenterology 2007, 133, 496-506. [CrossRef] [PubMed]

69. Alberti, K.G.M.M.; Eckel, R.H.; Grundy, S.M.; Zimmet, P.Z.; Cleeman, J.I.; Donato, K.A.; Fruchart, J.-C.; James, W.P.T.; Loria, C.M.; Smith, S.C.; et al. Harmonizing the metabolic syndrome: A joint interim statement of the international diabetes federation task force on epidemiology and prevention; national heart, lung, and blood institute; American heart association; world heart federation; international atherosclerosis society; and international association for the study of obesity. Circulation 2009, 120, 1640-1645. [PubMed]

70. Manley, S.E.; Stratton, I.M.; Clark, P.M.; Luzio, S.D. Comparison of 11 human insulin assays: Implications for clinical investigation and research. Clin. Chem. 2007, 53, 922-932. [CrossRef] [PubMed]

71. Sookoian, S.; Pirola, C.J. Meta-analysis of the influence of I148M variant of patatin-like phospholipase domain containing 3 gene (PNPLA3) on the susceptibility and histological severity of nonalcoholic fatty liver disease. Hepatology 2011, 53, 1883-1894. [CrossRef] [PubMed]

72. Zhang, L.; You, W.; Zhang, H.; Peng, R.; Zhu, Q.; Yao, A.; Li, X.; Zhou, Y.; Wang, X.; Pu, L.; et al. PNPLA3 polymorphisms (rs738409) and non-alcoholic fatty liver disease risk and related phenotypes: A meta-analysis. J. Gastroenterol. Hepatol. 2015, 30, 821-829. [CrossRef] [PubMed]

73. Xu, R.; Tao, A.; Zhang, S.; Deng, Y.; Chen, G. Association between patatin-like phospholipase domain containing 3 gene (PNPLA3) polymorphisms and nonalcoholic fatty liver disease: A HuGE review and meta-analysis. Sci. Rep. 2015, 5. [CrossRef]

74. Shen, J.-H.; Li, Y.-L.; Li, D.; Wang, N.-N.; Jing, L.; Huang, Y.-H. The rs738409 (I148M) variant of the PNPLA3 gene and cirrhosis: A meta-analysis. J. Lipid Res. 2015, 56, 167-175. [CrossRef]

75. Trépo, E.; Nahon, P.; Bontempi, G.; Valenti, L.; Falleti, E.; Nischalke, H.D.; Hamza, S.; Corradini, S.G.; Burza, M.A.; Guyot, E.; et al. Association between the PNPLA3 (rs738409 C>G) variant and hepatocellular carcinoma: Evidence from a meta-analysis of individual participant data. Hepatology 2014, 59, 2170-2177. [CrossRef]

76. He, S.; McPhaul, C.; Li, J.Z.; Garuti, R.; Kinch, L.; Grishin, N.V.; Hobbs, H.H. A sequence variation (I148M) in PNPLA3 associated with nonalcoholic fatty liver disease disrupts triglyceride hydrolysis. J. Biol. Chem. 2010, 285, 6706-6715. [CrossRef]

77. Huang, Y.; Cohen, J.C.; Hobbs, H.H. Expression and characterization of a PNPLA3 protein isoform (I148M) associated with nonalcoholic fatty liver disease. J. Biol. Chem. 2011, 286, 37085-37093. [CrossRef] [PubMed]

78. Kumari, M.; Schoiswohl, G.; Chitraju, C.; Paar, M.; Cornaciu, I.; Rangrez, A.Y.; Wongsiriroj, N.; Nagy, H.M.; Ivanova, P.T.; Scott, S.A.; et al. Adiponutrin functions as a nutritionally regulated lysophosphatidic acid acyltransferase. Cell Metab. 2012, 15, 691-702. [CrossRef] [PubMed]

79. Kantartzis, K.; Peter, A.; Machicao, F.; Machann, J.; Wagner, S.; Königsrainer, I.; Königsrainer, A.; Schick, F.; Fritsche, A.; Haring, H.-U.; et al. Dissociation between fatty liver and insulin resistance in humans carrying a variant of the patatin-like phospholipase 3 gene. Diabetes 2009, 58, 2616-2623. [CrossRef] [PubMed] 
80. Kotronen, A.; Johansson, L.E.; Johansson, L.M.; Roos, C.; Westerbacka, J.; Hamsten, A.; Bergholm, R.; Arkkila, P.; Arola, J.; Kiviluoto, T.; et al. A common variant in PNPLA3, which encodes adiponutrin, is associated with liver fat content in humans. Diabetologia 2009, 52, 1056-1060. [CrossRef] [PubMed]

81. Scorletti, E.; West, A.L.; Bhatia, L.; Hoile, S.P.; McCormick, K.G.; Burdge, G.C.; Lillycrop, K.A.; Clough, G.F.; Calder, P.C.; Byrne, C.D. Treating liver fat and serum triglyceride levels in NAFLD, effects of PNPLA3 and TM6SF2 genotypes: Results from the WELCOME trial. J. Hepatol. 2015, 63, 1476-1483. [CrossRef] [PubMed]

82. Wagenknecht, L.E.; Palmer, N.D.; Bowden, D.W.; Rotter, J.I.; Norris, J.M.; Ziegler, J.; Chen, Y.D.I.; Haffner, S.; Scherzinger, A.; Langefeld, C.D. Association of PNPLA3 with non-alcoholic fatty liver disease in a minority cohort: The insulin resistance atherosclerosis family study. Liver Int. 2011, 31, 412-416. [CrossRef] [PubMed]

83. Verrijken, A.; Beckers, S.; Francque, S.; Hilden, H.; Caron, S.; Zegers, D.; Ruppert, M.; Hubens, G.; Marck, E.; Michielsen, P.; et al. A gene variant of PNPLA3, but not of APOC3, is associated with histological parameters of NAFLD in an obese population. Obesity (Silver Spring) 2013, 21, 2138-2145. [CrossRef] [PubMed]

84. Musso, G.; Cassader, M.; Gambino, R. PNPLA3 rs738409 and TM6SF2 rs58542926 gene variants affect renal disease and function in nonalcoholic fatty liver disease. Hepatology 2015, 62, 658-659. [CrossRef] [PubMed]

85. Valenti, L.; Al-Serri, A.; Daly, A.K.; Galmozzi, E.; Rametta, R.; Dongiovanni, P.; Nobili, V.; Mozzi, E.; Roviaro, G.; Vanni, E.; et al. Homozygosity for the patatin-like phospholipase-3/adiponutrin I148M polymorphism influences liver fibrosis in patients with nonalcoholic fatty liver disease. Hepatology 2010, 51, 1209-1217. [CrossRef] [PubMed]

86. Del Ben, M.; Polimeni, L.; Brancorsini, M.; di Costanzo, A.; D’Erasmo, L.; Baratta, F.; Loffredo, L.; Pastori, D.; Pignatelli, P.; Violi, F.; et al. Non-alcoholic fatty liver disease, metabolic syndrome and patatin-like phospholipase domain-containing protein3 gene variants. Eur. J. Intern. Med. 2014, 25, 566-570. [CrossRef] [PubMed]

87. Wang, C.W.; Lin, H.Y.; Shin, S.J.; Yu, M.-L.; Lin, Z.-Y.; Dai, C.-Y.; Huang, J.-F.; Chen, S.-C.; Li, S.S.L.; Chuang, W.-L. The PNPLA3 I148M polymorphism is associated with insulin resistance and nonalcoholic fatty liver disease in a normoglycaemic population. Liver Int. 2011, 31, 1326-1331. [CrossRef] [PubMed]

88. Park, J.H.; Cho, B.; Kwon, H.; Prilutsky, D.; Yun, J.M.; Choi, H.C.; Hwang, K.B.; Lee, I.H.; Kim, J.I.; Kong, S.W. I148M variant in PNPLA3 reduces central adiposity and metabolic disease risks while increasing nonalcoholic fatty liver disease. Liver Int. 2015, 35, 2537-2546. [CrossRef] [PubMed]

89. Lin, Y.-C.; Chang, P.-F.; Hu, F.-C.; Yang, W.-S.; Chang, M.-H.; Ni, Y.-H. A Common variant in the PNPLA3 gene is a risk factor for Non-alcoholic fatty liver disease in obese Taiwanese children. J. Pediatr. 2011, 158, 740-744. [CrossRef] [PubMed]

90. Romeo, S.; Sentinelli, F.; Cambuli, V.M.; Incani, M.; Congiu, T.; Matta, V.; Pilia, S.; Huang-Doran, I.; Cossu, E.; Loche, $\mathrm{S}$; et al. The $148 \mathrm{M}$ allele of the PNPLA3 gene is associated with indices of liver damage early in life. J. Hepatol. 2010, 53, 335-338. [CrossRef] [PubMed]

91. Valenti, L.; Alisi, A.; Galmozzi, E.; Bartuli, A.; del Menico, B.; Alterio, A.; Dongiovanni, P.; Fargion, S.; Nobili, V. I148M patatin-like phospholipase domain-containing 3 gene variant and severity of pediatric nonalcoholic fatty liver disease. Hepatology 2010, 52, 1274-1280. [CrossRef] [PubMed]

92. Kozlitina, J.; Smagris, E.; Stender, S.; Nordestgaard, B.G.; Zhou, H.H.; Tybjærg-Hansen, A.; Vogt, T.F.; Hobbs, H.H.; Cohen, J.C. Exome-wide association study identifies a TM6SF2 variant that confers susceptibility to nonalcoholic fatty liver disease. Nat. Genet. 2014, 46, 352-356. [CrossRef] [PubMed]

93. Pirola, C.J.; Sookoian, S. The dual and opposite role of the TM6SF2-rs58542926 variant in protecting against cardiovascular disease and conferring risk for nonalcoholic fatty liver: A meta-analysis. Hepatology 2015, 62, 1742-1756. [CrossRef] [PubMed]

94. Smagris, E.; Gilyard, S.; BasuRay, S.; Cohen, J.C.; Hobbs, H.H. Inactivation of TM6SF2, a gene defective in fatty liver disease, impairs lipidation but not secretion of very low density lipoproteins. J. Biol. Chem. 2016. [CrossRef] [PubMed]

95. Mahdessian, H.; Taxiarchis, A.; Popov, S.; Silveira, A.; Franco-Cereceda, A.; Hamsten, A.; Eriksson, P.; van't Hooft, F. TM6SF2 is a regulator of liver fat metabolism influencing triglyceride secretion and hepatic lipid droplet content. Proc. Natl. Acad. Sci. USA 2014, 111, 8913-8918. [CrossRef] [PubMed]

96. Holmen, O.L.; Zhang, H.; Fan, Y.; Hovelson, D.H.; Schmidt, E.M.; Zhou, W.; Guo, Y.; Zhang, J.; Langhammer, A.; Løchen, M.-L.; et al. Systematic evaluation of coding variation identifies a candidate causal variant in TM6SF2 influencing total cholesterol and myocardial infarction risk. Nat. Genet. 2014, 46, 345-351. [CrossRef] [PubMed] 
97. Zhou, Y.; Llauradó, G.; Orešič, M.; Hyötyläinen, T.; Orho-Melander, M.; Yki-Järvinen, H. Circulating triacylglycerol signatures and insulin sensitivity in NAFLD associated with the E167K variant in TM6SF2. J. Hepatol. 2015, 62, 657-663. [CrossRef] [PubMed]

98. Eslam, M.; Mangia, A.; Berg, T.; Chan, H.L.-Y.; Irving, W.L.; Dore, G.J.; Abate, M.L.; Bugianesi, E.; Adams, L.A.; Najim, M.A.M.; et al. Diverse impacts of the rs58542926 E167K variant in TM6SF2 on viral and metabolic liver disease phenotypes. Hepatology 2016. [CrossRef] [PubMed]

99. Goffredo, M.; Caprio, S.; Feldstein, A.E.; D'Adamo, E.; Shaw, M.M.; Pierpont, B.; Savoye, M.; Zhao, H.; Bale, A.E.; Santoro, N. Role of TM6SF2 rs58542926 in the pathogenesis of nonalcoholic pediatric fatty liver disease: A multiethnic study. Hepatology 2016, 63, 117-125. [CrossRef] [PubMed]

100. Grandone, A.; Cozzolino, D.; Marzuillo, P.; Cirillo, G.; di Sessa, A.; Ruggiero, L.; di Palma, M.R.; Perrone, L.; Miraglia del Giudice, E. TM6SF2 Glu167Lys polymorphism is associated with low levels of LDL-cholesterol and increased liver injury in obese children. Pediatr. Obes. 2016, 11, 115-119. [CrossRef] [PubMed]

101. European Association for the Study of the Liver (EASL); European Association for the Study of Diabetes (EASD); European Association for the Study of Obesity (EASO). EASL-EASD-EASO Clinical Practice Guidelines for the management of non-alcoholic fatty liver disease. Diabetologia 2016, 9, 65-90.

(C) 2016 by the authors; licensee MDPI, Basel, Switzerland. This article is an open access article distributed under the terms and conditions of the Creative Commons Attribution (CC-BY) license (http://creativecommons.org/licenses/by/4.0/). 